\title{
DNA Relatedness among Nonpigmented Species of Alteromonas and Synonymy of Alteromonas haloplanktis (ZoBell and Upham 1944) Reichelt and Baumann 1973 and Alteromonas tetraodonis Simidu et al. 1990
}

\author{
MASAYO AKAGAWA-MATSUSHITA, ${ }^{1 *}$ YOSUKE KOGA, ${ }^{1}$ AND KAZUHIDE YAMASATO ${ }^{2}$ \\ Department of Chemistry, University of Occupational and Environmental Health, Yahatanishi-ku, Kitakyushu \\ $807,{ }^{1}$ and Institute of Applied Microbiology, The University of Tokyo, Bunkyo-ku, Tokyo $113,{ }^{2}$ Japan
}

The taxonomic relationships among nonpigmented species of the genus Alteromonas were assessed by DNA-DNA hybridization. The species formed two groups based on DNA homology values and moles percent G+C of DNA: Alteromonas macleodii, the type species, had a moles percent $G+C$ content 4 to $7 \%$ higher than those of the other group, and it had less than 5\% DNA homology to the second group formed by the remaining species. The remaining species formed seven DNA homology subgroups, of which five corresponded to the type strains of $A$. atlantica, $A$. espejiana, $A$. carrageenovora, $A$. undina, and $A$. nigrifaciens. A sixth subgroup included the type strains of $A$. haloplanktis and $A$. tetraodonis, which showed hybridizations of more than $80 \%$. The species in the second group were related to each other at the genus level, but a nomenclatural proposal is postponed. The hybridization data showed that the name $A$. tetraodonis Simidu et al. 1990 should be recognized as a junior subjective synomyn of $A$, haloplanktis (ZoBell and Upham 1944) Reichelt and Baumann 1973. The seventh subgroup included two as yet unassigned strains which were misidentified as to species.

The genus Alteromonas originally consisted of three species of gram-negative, aerobic, nonpigmented, polarly flagellated marine bacteria which resembled Pseudomonas but had a lower moles percent $\mathrm{G}+\mathrm{C}$ content (38 to $50 \%$ ) (5). A further seven nonpigmented and five pigmented species have since been described as members of the genus. The phylogenetic analysis by rRNA-DNA hybridization reported by Van Landschoot and De Ley (22) showed that the genus

TABLE 1. Strains used ${ }^{a}$

\begin{tabular}{|c|c|c|c|c|c|}
\hline Species & Strain & Source & Other designation(s) & Previous assignment ${ }^{b}$ & Reference(s) \\
\hline Alteromonas macleodii & IAM $12920^{\mathrm{T}}$ & ATCC 27126 & NCIMB 1963, Baumann 107 & & $5,10,22$ \\
\hline Alteromonas atlantica & IAM $12927^{\mathbf{T}}$ & NCIMB 301 & $\begin{array}{l}\text { ATCC 19262, IAM 12376, } \\
\text { CIP 63.28, JCM } 8845\end{array}$ & "Pseudomonas atlantica" & $2,22,23$ \\
\hline $\begin{array}{l}\text { Alteromonas carrageeno - } \\
\text { vora }\end{array}$ & IAM $12662^{\mathrm{T}}$ & IFO 12985 & $\begin{array}{l}\text { ATCC } 43555, \text { NCIMB } 302, \\
\text { CIP } 103674, \text { JCM } 8851\end{array}$ & "Pseudomonas carrageenovora" & $2,11,22$ \\
\hline Alteromonas espejiana & IAM $12640^{\mathrm{T}}$ & ATCC 29659 & NCIMB 2127, Baumann 261 & & 9,22 \\
\hline Alteromonas haloplanktis & IAM $12915^{\mathrm{T}}$ & ATCC 14393 & $\begin{array}{l}\text { NCIMB 2084, ZoBell \& Up- } \\
\text { ham 545, Baumann et al. } \\
215\end{array}$ & "Vibrio haloplanktis" & 17,22 \\
\hline Alteromonas haloplanktis & IAM 12916 & ATCC 19648 & Johnson ASU-1 & "Vibrio marinopraescens" & 22 \\
\hline Alteromonas haloplanktis & IAM 12917 & ATCC 23821 & NCIMB 1545, Colwell 651 & "Pseudomonas enalia" & 17,22 \\
\hline Alteromonas haloplanktis & IAM 12918 & ATCC 27127 & NCIMB 1964, Baumann 121 & "Alteromonas marinopraescens" & 17,22 \\
\hline Alteromonas haloplanktis & IAM 12919 & NCIMB 19 & ATCC 19855, MacLeod B-16 & Pseudomonas sp. & \\
\hline $\begin{array}{l}\text { Alteromonas undina } \\
\text { Alteromonas undina }\end{array}$ & $\begin{array}{l}\text { IAM } 12922^{\mathrm{T}} \\
\text { NS-110 }\end{array}$ & $\begin{array}{l}\text { ATCC } 29660 \\
\text { M. Maeda }\end{array}$ & NCIMB 2128, Baumann 272 & & 9,22 \\
\hline Alteromonas nigrifaciens & IAM $13010^{\mathrm{T}}$ & ATCC 19375 & $\begin{array}{l}\text { NCIMB } 8614, \text { NCTC 10691, } \\
\text { NCDO } 755\end{array}$ & "Pseudomonas nigrifaciens" & $6,8,10,22$ \\
\hline $\begin{array}{l}\text { Alteromonas nigrifaciens } \\
\text { Alteromonas tetraodonis }\end{array}$ & $\begin{array}{l}\text { IAM } 13161 \\
\text { IAM } 14160^{T}\end{array}$ & $\begin{array}{l}\text { ATCC } 25013 \\
\text { U. Simidu }\end{array}$ & & & $6,11,22$ \\
\hline Marinomonas communis & IAM $12914^{\mathrm{T}}$ & ATCC 27118 & NCIMB 1961, Baumann 8 & Alteromonas communis & $5,8,22$ \\
\hline Marinomonas vaga & IAM $12923^{\mathrm{T}}$ & ATCC 27119 & NCIMB 1962, Baumann 40 & Alteromonas vaga & $5,8,22$ \\
\hline Escherichia coli & IAM 1264 & ATCC 10798 & & & \\
\hline
\end{tabular}

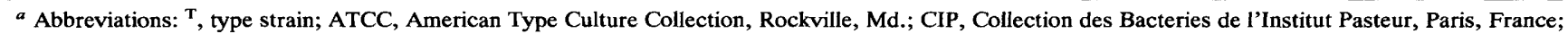
JCM, Japan Collection of Microorganisms, RIKEN, Wako-shi, Saitama, Japan; IAM, Institute of Molecular and Cellular Biosciences (formerly Institute of Applied Microbiology), The University of Tokyo, Bunkyo-ku, Tokyo, Japan; IFO, Institute for Fermentation Osaka, Osaka, Japan; NCDO, Natinal Collection of Dairy Organisms, Reading, England; NCIMB, National Collections of Industrial and Marine Bacteria, NCIMB Ltd., Torry Research Station, Aberdeen, Scotland; NCTC, National Collection of Type Cultures, London, England.

${ }^{b}$ Names in quotation marks have not been validated.

$c$ National Research Institute of Aquaculture, Nansei, Mie, Japan.

${ }^{d}$ Ocean Research Institute, The University of Tokyo, Nakano-ku, Tokyo, Japan.

\footnotetext{
* Corresponding author.
} 
TABLE 2. DNA relatedness among Alteromonas strains

\begin{tabular}{|c|c|c|c|c|c|c|c|c|c|c|}
\hline \multirow[b]{2}{*}{ Strain } & \multirow{2}{*}{$\begin{array}{l}\mathrm{G}+\mathrm{C} \\
\text { content } \\
(\mathrm{mol} \%)\end{array}$} & \multicolumn{9}{|c|}{$\%$ Reassociation with ${ }^{3} \mathrm{H}$-labeled DNA from ${ }^{a}$ : } \\
\hline & & $\begin{array}{l}\text { A. macleodii } \\
\text { IAM } 12920^{T}\end{array}$ & $\begin{array}{l}\text { A. atlantica } A \text {. } \\
\text { LAM } 12927^{\mathrm{T}}\end{array}$ & $\begin{array}{l}\text { carrageenovora } \\
\text { IAM } 12662^{T}\end{array}$ & $\begin{array}{l}\text { A. espejiana } \\
\text { IAM } 12640^{\mathrm{T}}\end{array}$ & $\begin{array}{l}\text { A. haloplanktis } \\
\text { IAM } 12915^{\mathrm{T}}\end{array}$ & $\begin{array}{l}\text { A. tetraodonis } \\
\text { IAM } 14160^{T}\end{array}$ & $\begin{array}{l}\text { A. undina } \\
\text { IAM } \\
12922^{\mathrm{T}}\end{array}$ & $\begin{array}{l}\text { A. undina } \\
\text { NS-110 }\end{array}$ & $\begin{array}{l}\text { A. nigrifaciens } \\
\text { IAM } 13010^{\mathrm{T}}\end{array}$ \\
\hline $\begin{array}{l}\text { A. macleodii IAM } \\
12920^{\mathrm{T}}\end{array}$ & $46.2^{b}$ & 100 & $6^{b}$ & $4^{b}$ & $7^{b}$ & 5 & 6 & 8 & 7 & 5 \\
\hline $\begin{array}{l}\text { A. atlantica IAM } \\
12927^{\mathrm{T}}\end{array}$ & $41.2^{b}$ & 5 & 100 & $26^{b}$ & $40^{b}$ & 30 & $23^{b}$ & 19 & 18 & 28 \\
\hline $\begin{array}{l}\text { A. carageenovora } \\
\text { IAM } 12662^{\mathrm{T}}\end{array}$ & $39.5^{b}$ & 4 & $21^{b}$ & 100 & $43^{b}$ & 21 & $26^{b}$ & 27 & 32 & 24 \\
\hline $\begin{array}{l}\text { A. espejiana IAM } \\
12640^{\mathrm{T}}\end{array}$ & $41.4^{b}$ & 5 & $43^{b}$ & $45^{b}$ & 100 & 41 & $22^{b}$ & 17 & & 20 \\
\hline $\begin{array}{l}\text { A. haloplanktis } \\
\text { IAM } 12915^{\mathrm{T}}\end{array}$ & $41.6^{b}$ & 2 & $27^{b}$ & $21^{b}$ & $23^{b}$ & 100 & 84 & 57 & 42 & 35 \\
\hline $\begin{array}{l}\text { A. haloplanktis } \\
\text { IAM } 12916\end{array}$ & 40.5 & & & & & 80 & 81 & 51 & 39 & \\
\hline $\begin{array}{l}\text { A. haloplanktis } \\
\text { IAM } 12917\end{array}$ & 40.9 & & & & & 87 & 109 & 61 & 62 & \\
\hline $\begin{array}{l}\text { A. tetraodonis } \\
\text { IAM } 14160^{\mathrm{T}}\end{array}$ & $40.8^{b}$ & & 30 & 27 & 19 & 82 & 100 & 50 & 48 & 36 \\
\hline $\begin{array}{l}\text { A. undina IAM } \\
12922^{\mathrm{T}}\end{array}$ & $40.1^{b}$ & & $25^{b}$ & $21^{b}$ & $25^{b}$ & 47 & 52 & 100 & 100 & 22 \\
\hline A. undina NS-110 & 40.3 & & 25 & 21 & 36 & 59 & 57 & 97 & 100 & \\
\hline $\begin{array}{l}\text { A. nigrifaciens } \\
\text { IAM } 13010^{\mathrm{T}}\end{array}$ & $40.6^{b}$ & 5 & $32^{b}$ & $23^{b}$ & $21^{b}$ & 35 & 30 & 32 & 31 & 100 \\
\hline $\begin{array}{l}\text { A. haloplanktis } \\
\text { IAM } 12919\end{array}$ & 41.1 & 5 & 39 & 40 & 27 & 33 & & 23 & & 67 \\
\hline $\begin{array}{l}\text { A. haloplanktis } \\
\text { IAM } 12918\end{array}$ & 42.2 & 4 & 19 & 14 & 11 & 16 & & 13 & & 12 \\
\hline $\begin{array}{l}\text { A. nigrifaciens } \\
\text { IAM } 13161\end{array}$ & & & & & & 22 & 29 & 23 & & 31 \\
\hline $\begin{array}{l}\text { M. communis } \\
\text { IAM } 12914^{T}\end{array}$ & $47.0^{b}$ & 4 & $4^{b}$ & $4^{b}$ & $5^{b}$ & 4 & 3 & 5 & 3 & 3 \\
\hline $\begin{array}{l}\text { M. vaga IAM } \\
12923^{\mathrm{T}}\end{array}$ & $48.4^{b}$ & 3 & $4^{b}$ & $4^{b}$ & $4^{b}$ & 4 & 3 & 3 & 3 & 4 \\
\hline E. coli IAM 1264 & $51.3^{b}$ & 5 & $4^{b}$ & $3^{b}$ & $3^{b}$ & 3 & $4^{b}$ & 4 & 7 & 5 \\
\hline
\end{tabular}

a Reassociation values are averages of four independent determinations.

$b$ Data from reference 2 .

Alteromonas consisted of two rRNA groups which were so remotely related as to warrant separate families (11). They also showed that several Pseudomonas species should be classified as members of the genus Alteromonas but left them unassigned. Alteromonas species and Alteromonaslike bacteria are widely distributed and frequently isolated from marine environments. They are ecologically and economically important microorganisms $(3,4,12-16,18,21)$.

The identification of Alteromonas-like isolates is difficult because of great intraspecific variation in their characters. Most species were proposed on a biochemical and nutritional basis combined with taxometric clustering $(6,7,9,12)$. They were described mostly without genetic evidence, except for two recently described species, Alteromonas atlantica and $A$. carrageenovora (2). The proposal of $A$. tetraodonis was supported by partial sequencing of $16 \mathrm{~S}$ rRNA (19). The nonpigmented species of Alteromonas are physiologically similar (2), and the identification and classification of such strains need genetic analysis.
In this study DNA-DNA hybridization experiments were performed to confirm the validity of the existing species and to clarify the taxonomic structure of the genus Alteromonas, with particular attention to nonpigmented species.

\section{MATERIALS AND METHODS}

Bacterial strains. The strains of Alteromonas that we used are listed in Table 1. Two type strains of Marinomonas species and Escherichia coli IAM 1264 (strain K-12) were included for reference. All strains were maintained on slopes of Marine Agar 2216 (Difco Laboratories, Detroit, Mich.) at $25^{\circ} \mathrm{C}$ and transferred every month. For long-term preservation, cell suspensions in Marine Broth 2216 (Difco) supplemented with $10 \%$ glycerol were stored in liquid nitrogen.

Determination of DNA base composition and DNA-DNA hybridization. Methods for DNA preparation were described previously (1). The determination of the moles percent $\mathrm{G}+\mathrm{C}$ content of DNA involved high-performance liquid chroma- 
tography as described by Tamaoka and Komagata (20), using a DNA-GC kit (Yamasa shoyu, Choshi, Japan). DNA-DNA hybridization was carried out by the membrane filter method under nonstringent conditions $(2 \times \mathrm{SSC}[1 \times \mathrm{SSC}$ is $0.15 \mathrm{M}$ $\mathrm{NaCl}$ plus $0.015 \mathrm{M}$ sodium citrate] plus $0.1 \%$ sodium dodecyl sulfate, $62^{\circ} \mathrm{C}$ ) by a procedure we have employed previously (2).

\section{RESULTS AND DISCUSSION}

The moles percent $\mathrm{G}+\mathrm{C}$ content of DNAs and percent homology values for all of the strains we studied are presented in Table 2. The distinctness of the $\mathrm{G}+\mathrm{C}$ moles percent values and the very low DNA homology values between $A$. macleodii, the type species, and the other species of the genus reflect the phylogenetic unrelatedness that has been shown by rRNA-DNA hybridizations (22). The nonpigmented Alteromonas species were thus divided into two obvious groups. Table 2 shows seven subgroups apart from the type species; five of these included the type strains of a species (A. atlantica, $A$. carrageenovora, $A$. espejiana, $A$. undina, and $A$. nigrifaciens). One of the subgroups included the type strains of both $A$. haloplanktis and $A$. tetraodonis, which showed 82 to $84 \%$ hybridization. It showed $<5 \%$ homology with either Marinomonas communis or Marinomonas vaga, which had been inferred as relatives by Simidu et al. (19) on the basis of sequence similarity of 16S rRNA. 16S rRNA is not suitable for establishing relationships at this level. The data in Table 2 indicate that the type strain of $A$. tetraodonis is highly related to $A$. haloplanktis strains. We conclude that the name $A$. tetraodonis Simidu et al. 1990 should be rejected because it is a junior subjective synonym of $A$. haloplanktis (ZoBell and Upham 1944)

Reichelt and Baumann 1973.

When Chan et al. (9) described $A$. undina as a new species, the closest relative was reported to be $A$. haloplank$t$ tis on the basis of numerical analysis of phenotypic features. The homology values presented here (39 to $62 \%$ ) support their finding from the standpoint of genotypic similarity.

Our results indicate three strains maintained in culture collections as $A$. haloplanktis. Strain IAM 12919 (= NCIMB 19 and ATCC 19855), which was previously identified as a Pseudomonas sp., has been extensively used in nutritional and cell structure studies (7) and appears to belong to $A$. nigrifaciens. Strains IAM 12918 (= ATCC 27127) and IAM 13161 (= ATCC 25013) also prove to be misnamed. However, more-extensive taxonomic investigation, including phenotypic characterization, is necessary for conclusive assignments.

Among the species $A$. atlantica, $A$. espejiana, $A$. carrageenovora, $A$. haloplanktis, $A$. undina, and $A$. nigrifaciens, which are placed on the $A$. haloplanktis rRNA branch (22), 18 to $62 \%$ homology values were observed. Such values can be considered the indices of the relationships between species in a same genus under the condition used in this study. Homology values between DNAs from $A$. macleodii IAM $12920^{\mathrm{T}}$ and other Alteromonas strains were from 2 to $8 \%$. These values were, under the tested conditions, as low as those between the unrelated strains $E$. coli and Alteromonas strains and as those between the strains belonging to different rRNA branches according to the criteria of Van Landschoot and De Ley (22).

Consideration should be given to dividing the genus Alteromonas into at least two genera. If that were done, the generic name Alteromonas would have to be restricted to $A$. macleodii.

\section{ACKNOWLEDGMENTS}

We thank M. Maeda (National Research Institute of Aquaculture, Nansei, Mie, Japan) for kindly supplying cultures.

\section{REFERENCES}

1. Akagawa, M., and K. Yamasato. 1989. Synonymy of Alcaligenes aquamarinus, Alcaligenes faecalis subsp. homari, and Deleya aesta: Deleya aquamarina comb. nov. as the type species of the genus Deleya. Int. J. Syst. Bacteriol. 39:462-466.

2. Akagawa-Matsushita, M., M. Matsuo, Y. Koga, and K. Yamasato. 1992. Alteromonas atlantica sp. nov. and Alteromonas carrageenovora sp. nov., bacteria that decompose algal polysaccharides. Int. J. Syst. Bacteriol. 42:621-627.

3. Ando, S., A. Yoshida, K. Nakajima, and M. Hatano. 1991. Hydrolysis of fish oil by marine bacterial lipase. Nihon Suisan Gakkaishi 57:1351-1353.

4. Andrykovitch, G., and I. Marx. 1988. Isolation of a new polysaccharide-digesting bacterium from a salt marsh. Appl. Environ. Microbiol. 54:1061-1062.

5. Baumann, L., P. Baumann, M. Mandel, and R. D. Allen. 1972. Taxonomy of aerobic marine eubacteria. J. Bacteriol. 110:402429.

6. Baumann, P., L. Baumann, R. D. Bowditch, and B. Beaman. 1984. Taxonomy of Alteromonas: A. nigrifaciens sp. nov., nom. rev.; $A$. macleodii; and $A$. haloplanktis. Int. J. Syst. Bacteriol. 34:145-149.

7. Baumann, P., M. J. Gauthier, and L. Baumann. 1984. Genus Alteromonas Baumann, Baumann, Mandel and Allen 1972, 418. ${ }^{\text {AL }}$, p. 343-352. In N. R. Krieg and J. G. Holt (ed.), Bergey's manual of systematic bacteriology, vol. 1. The Williams \& Wilkins Co., Baltimore.

8. Bowditch, R. D., L. Baumann, and P. Baumann. 1984. Description of Oceanospirillum kriegii sp. nov. and $O$. jannaschii sp. nov. and assignment of two species of Alteromonas to this genus as $O$. commune comb. nov. and $O$. vagum comb. nov. Curr. Microbiol. 10:221-230.

9. Chan, K. Y., L. Baumann, M. M. Garza, and P. Baumann. 1978. Two new species of Alteromonas: Alteromonas espejiana and Alteromonas undina. Int. J. Syst. Bacteriol. 28:217-222.

10. Coyne, V. E., C. J. Pillidge, D. D. Sledjeski, H. Hori, B. A. Ortiz-Conde, D. G. Muir, R. M. Weiner, and R. R. Colwell. 1989. Reclassification of Alteromonas colwelliana to the genus Shewanella by DNA-DNA hybridization, serology and 5S ribosomal RNA sequence data. Syst. Appl. Microbiol. 12:275-279.

11. De Vos, P., A. Van Landschoot, P. Segers, R. Tytgat, M. Gillis, M. Bauwens, R. Rossau, M. Goor, B. Pot, K. Kersters, P. Lizzaraga, and J. De Ley. 1989. Genotypic relationships and taxonomic localization of unclassified Pseudomonas and Pseudomonas-like strains by deoxyribonucleic acid:ribosomal ribonucleic acid hybridizations. Int. J. Syst. Bacteriol. 39:3549.

12. Enger, O., H. Nygaard, M. Solberg, G. Schei, J. Nielsen, and I. Dundas. 1987. Characterization of Alteromonas denitrificans sp. nov. Int. J. Syst. Bacteriol. 37:416-421.

13. Gauthier, M. J. 1976. Alteromonas rubra sp. nov., a new marine antibiotic-producing bacterium. Int. J. Syst. Bacteriol. 26:459_ 466.

14. Gauthier, M. J. 1977. Alteromonas citrea, a new gram-negative, yellow-pigmented species from seawater. Int. J. Syst. Bacteriol. 27:349-354.

15. Gauthier, M. J., and V. A. Breittmayer. 1979. A new antibioticproducing bacterium from seawater: Alteromonas aurantia $\mathrm{sp.}$ nov. Int. J. Syst. Bacteriol. 29:366-372.

16. Imada, C., U. Simidu, and N. Taga. 1985. Isolation and characterization of marine bacteria producing alkaline protease inhibitor. Bull. Jpn. Soc. Sci. Fish. 52:799-803.

17. Reichelt, J. L., and P. Baumann. 1973. Change of the name Alteromonas marinopraescens (ZoBell and Upham) Baumann et al. to Alteromonas haloplanktis (ZoBell and Upham) comb. 
nov. and assignment of strain ATCC 23821 (Pseudomonas enalia) and strain c-Al of De Voe and Oginsky to this species. Int. J. Syst. Bacteriol. 23:438-441.

18. Sawabe, T., Y. Ezura, and T. Kimura. 1992. Characterization of an alginolytic marine bacterium from decaying Rishiri-kombu Laminaria japonica var. ochotensis. Nihon Suisan Gakkaishi 58:141-145.

19. Simidu, U., K. Kita-Tsukamoto, T. Yasumoto, and M. Yotsu. 1990. Taxonomy of four marine bacterial strains that produce tetrodotoxin. Int. J. Syst. Bacteriol. 40:331-336.

20. Tamaoka, J., and K. Komagata. 1984. Determination of DNA base composition by reversed-phase high-performance liquid chromatography. FEMS Microbiol. Lett. 25:125-128.

21. Tsujibo, H., Y. Yoshida, C. Imada, Y. Okami, K. Miyamoto, and Y. Inamori. Isolation and characterization of a chitin degrading marine bacterium belonging to the genus Alteromonas. Nihon Suisan Gakkaishi 57:2127-2131.

22. Van Landschoot, A., and J. De Ley. 1983. Intra- and intergeneric similarities of the rRNA cistrons of Alteromonas, Marinomonas (gen. nov.) and some other Gram-negative bateria. J. Gen. Microbiol. 129:3057-3074

23. Yaphe, W. 1957. The use of agarase from Pseudomonas atlantica in the identification of agar in marine algae (Rhodophyceae). Can. J. Microbiol. 3:987-993. 